\title{
Syntheses, Characterization, Crystal Structures and Antimicrobial Activity of Schiff Base Copper(II) Complexes Derived from 2-Bromo-6-((2-(isopropylamino) ethylimino)methyl)phenol
}

\author{
Yong Yuan, ${ }^{1,}{ }^{*} \mathrm{Xi}-\mathrm{Kun} \mathrm{Lu},{ }^{1}$ Gao-Qi Zhou ${ }^{2}$ and Xiao-Yang Qiu ${ }^{2, *}$ \\ ${ }^{1}$ Institute of Automotive \& Mechanical and Electronic Engineering, ZhouKou Vocational and Technical College, \\ ZhouKou 466000, P. R. China \\ ${ }^{1}$ College of Science \& Technology, Ningbo University, Ningbo 315315, P. R. China \\ *Corresponding author: E-mail: xiaoyang_qiu@126.com (Xiao-Yang Qiu), \\ 2060349461@qq.com (Yong Yuan)
}

Received: 07-24-2021

\begin{abstract}
Three new copper(II) complexes, $\left[\mathrm{Cu}(\mathrm{LH})_{2}\right] \mathrm{Br}_{2}(\mathbf{1}),\left[\mathrm{Cu}(\mathrm{LH})_{2}\right] \mathrm{NCS}_{2}(\mathbf{2})$, and $\left[\mathrm{Cu}(\mathrm{LH})_{2}\right]\left(\mathrm{NO}_{3}\right)_{2}$ (3), where $\mathrm{LH}$ is the zwitterionic form of 2-bromo-6-((2-(isopropylamino)ethylimino)methyl)phenol (HL), were synthesized and characterized by elemental analysis, IR and UV-vis spectroscopy. The structures of the complexes were further confirmed by single crystal X-ray structure determination. All compounds are mononuclear copper(II) complexes. The $\mathrm{Cu}$ atoms in the complexes are coordinated by two imino $\mathrm{N}$ and two phenolate $\mathrm{O}$ atoms from two $\mathrm{LH}$ ligands, forming square planar coordination. The compounds were assayed for their antimicrobial activities.
\end{abstract}

Keywords: Schiff base; copper complex; crystal structure; antimicrobial activity

\section{Introduction}

The design and preparation of metal complexes with specific applications has been the subject of extensive research. The complexes with transition metals have been used in various chemical and biological applications. Among the complexes, those with Schiff base ligands have interesting structural diversity, and the possibility of the presence of various electron-donating or electron-withdrawing substituents. ${ }^{1}$ Schiff base copper complexes have been extensively studied and are considered as excellent alternatives for classic organic antibacterial, antifungal and antitumor. ${ }^{2}$ Despite the presence of a large number of studies on the antibacterial activities of such complexes, it is still necessary to explore new complexes with more effective activities. It has been proven that the compounds with electron-withdrawing substituent groups can improve their antimicrobial ability. ${ }^{3}$ Rai et al. reported some compounds with fluoro, chloro, bromo, and iodo-substituted groups, and their remarkable antimicrobial property. ${ }^{4}$ Schiff base complexes of copper have potential antibacterial property. ${ }^{5}$ Recently, our research group has re- ported some Schiff base complexes with biological properties. ${ }^{6}$ In pursuit of new Schiff base complexes with potential antimicrobial property, in this work, three new copper(II) complexes, $\left[\mathrm{Cu}(\mathrm{LH})_{2}\right] \mathrm{Br}_{2}(\mathbf{1}),\left[\mathrm{Cu}(\mathrm{LH})_{2}\right] \mathrm{NCS}_{2}$ (2), and $\left[\mathrm{Cu}(\mathrm{LH})_{2}\right]\left(\mathrm{NO}_{3}\right)_{2}(3)$, where $\mathrm{LH}$ is the zwitterionic form of 2-bromo-6-((2-(isopropylamino)ethylimino) methyl)phenol (HL), and their antimicrobial activities are present.

\section{Experimental}

\section{1. Materials and Methods}

3-Bromosalicylaldehyde, $\mathrm{N}$-isopropylethane-1,2-diamine, copper bromide, copper nitrate, and ammonium thiocyanate were obtained from Sigma-Aldrich. All other chemicals were commercial obtained from Xiya Chemical Co. Ltd. Elemental analyses of $\mathrm{C}, \mathrm{H}$ and $\mathrm{N}$ were carried out in a Perkin-Elmer automated model 2400 Series II CHNS/O analyzer. FT-IR spectra were obtained on a Perkin-Elmer 377 FT-IR spectrometer with samples prepared as $\mathrm{KBr}$ pellets. UV-Vis spectra were obtained on a Lambda 
35 spectrometer. Single crystal structural X-ray diffraction was carried out on a Bruker APEX II CCD diffractometer.

\section{2. Synthesis of HL}

3-Bromosalicylaldehyde $(1.0 \mathrm{mmol}, 0.20 \mathrm{~g})$ and $\mathrm{N}$-isopropylethane-1,2-diamine $(1.0 \mathrm{mmol}, 0.10 \mathrm{~g})$ were mixed and stirred in methanol $(30 \mathrm{~mL})$. The mixture was refluxed for $30 \mathrm{~min}$, and with the solvent removed by distillation. The solid product was recrystallized from methanol to give yellow product. Yield $87 \%$. Anal. calc. for $\mathrm{C}_{12} \mathrm{H}-$ ${ }_{17} \mathrm{BrN}_{2} \mathrm{O}$ : C, 50.54; H, 6.01; N, 9.82; found: C, 50.38; $\mathrm{H}$, 6.12; N, 9.73\%. IR data $\left(\mathrm{cm}^{-1}\right): 1634,1468,1381,1242$, $1098,928,915,457$. UV-Vis data $\left(\mathrm{MeOH}, \lambda_{\max }, \mathrm{nm}\right): 230$, $275,332,417$.

\section{3. Synthesis of Complex 1}

3-Bromosalicylaldehyde $(0.10 \mathrm{mmol}, 20 \mathrm{mg}), \mathrm{N}$-isopropylethane-1,2-diamine $(0.10 \mathrm{mmol}, 10 \mathrm{mg})$, and copper bromide $(0.10 \mathrm{mmol}, 22 \mathrm{mg})$ were mixed in methanol $(15 \mathrm{~mL})$ to give a clear blue solution. Block blue single crystals of the complex, suitable for X-ray diffraction, were grown from the solution upon slowly evaporation within 6 days. The crystals were isolated by filtration. Yield $32 \%$. Anal. calc. for $\mathrm{C}_{24} \mathrm{H}_{34} \mathrm{Br}_{4} \mathrm{CuN}_{4} \mathrm{O}_{2}$ : C, 36.32; $\mathrm{H}$, 4.32; N, 7.06; found: C, 36.13; H, 4.41; N, 9.91\%. IR data $\left(\mathrm{cm}^{-1}\right): 2971,2933,2816,2782,1618,1592,1530,1438$, 1391, 1329, 1228, 1186, 1132, 1073, 1035, 905, 843, 738, $671,612,550$. UV-Vis data $\left(\mathrm{MeOH}, \lambda_{\max }, \mathrm{nm}\right): 222,247$, $267,372$.

\section{4. Synthesis of Complex 2}

3-Bromosalicylaldehyde $(0.10 \mathrm{mmol}, 20 \mathrm{mg}), \mathrm{N}$-isopropylethane-1,2-diamine $(0.10 \mathrm{mmol}, 10 \mathrm{mg})$, copper bromide $(0.10 \mathrm{mmol}, 22 \mathrm{mg})$ and ammonium thiocyanate $(0.10 \mathrm{mmol}, 7.6 \mathrm{mg})$ were mixed in methanol $(15 \mathrm{~mL})$ to give a clear blue solution. Block blue single crystals of the complex, suitable for X-ray diffraction, were grown from the solution upon slowly evaporation within 4 days. The crystals were isolated by filtration. Yield $41 \%$. Anal. calc. for $\mathrm{C}_{26} \mathrm{H}_{34} \mathrm{Br}_{2} \mathrm{CuN}_{6} \mathrm{O}_{2} \mathrm{~S}_{2}$ : C, 41.63; H, 4.57; N, 11.20; found: C, $41.45 ; \mathrm{H}, 4.50 ; \mathrm{N}, 11.31 \%$. IR data $\left(\mathrm{cm}^{-1}\right): 2969,2939$, 2038, 1619, 1592, 1530, 1441, 1412, 1319, 1230, 1183, 1132, $1073,1031,905,850,781,739,663,617,549,473$. UV-Vis data $\left(\mathrm{MeOH}, \lambda_{\max }, \mathrm{nm}\right): 220,255,265,370$.

\section{5. Synthesis of Complex 3}

3-Bromosalicylaldehyde $(0.10 \mathrm{mmol}, 20 \mathrm{mg}), \mathrm{N}$-isopropylethane-1,2-diamine $(0.10 \mathrm{mmol}, 10 \mathrm{mg})$ and copper nitrate trihydrate $(0.10 \mathrm{mmol}, 24 \mathrm{mg})$ were mixed in methanol $(15 \mathrm{~mL})$ to give a clear blue solution. Block blue single crystals of the complex, suitable for X-ray diffraction, were grown from the solution upon slowly evaporation within 7 days. The crystals were isolated by filtration. Yield $27 \%$. Anal. calc. for $\mathrm{C}_{24} \mathrm{H}_{34} \mathrm{Br}_{2} \mathrm{CuN}_{6} \mathrm{O}_{8}: \mathrm{C}, 38.03 ; \mathrm{H}, 4.52 ; \mathrm{N}$, 11.09; found: C, 38.22; $\mathrm{H}, 4.61 ; \mathrm{N}, 10.93 \%$. IR data $\left(\mathrm{cm}^{-1}\right)$ : $2971,2937,1619,1590,1530,1443,1413,1382,1323,1230$, 1177, 1146, 1070, 1033, 905, 846, 753, 654, 632, 546, 461. UV-Vis data $\left(\mathrm{MeOH}, \lambda_{\max }, \mathrm{nm}\right): 220,250,265,373$.

\section{6. X-ray Crystallography}

$\mathrm{X}$-ray diffraction was carried out at a Bruker APEX II CCD area diffractometer equipped with MoKa radiation $(\lambda=0.71073 \AA)$. The collected data were reduced with SAINT, ${ }^{7}$ and multi-scan absorption correction was performed using SADABS. ${ }^{8}$ The structures of the complexes were solved by direct method, and refined against $F^{2}$ by full-matrix least-squares method using SHELXTL. ${ }^{9}$ All of the non-hydrogen atoms were refined anisotropically. The hydrogen atoms including those on nitrogen atoms were placed in calculated positions and constrained to ride on their parent atoms. The isopropyl group N4C22-C23-C24 is disordered over two sites, with occupancies of $0.48(3)$ and $0.52(3)$, respectively. The crystallographic data and refinement parameters for the complexes are listed in Table 1. Selected bond lengths and angles are listed in Table 2.

\section{7. Antimicrobial Assay}

The antibacterial property of the complexes was tested against Bacillus subtilis, Staphylococcus aureus, Escherichia coli, and Pseudomonas fluorescence using $\mathrm{MH}$ (Mueller-Hinton) medium. ${ }^{10}$ The antifungal activities of the compounds were tested against Candida albicans and Aspergillus niger using RPMI-1640 medium. The MIC values of the tested compounds were determined by a colorimetric method using the dye MTT. ${ }^{11}$ A stock solution of the compound $\left(150 \mu \mathrm{g} \mathrm{mL}^{-1}\right)$ in DMSO was prepared and graded quantities $\left(75 \mu \mathrm{g} \mathrm{mL}^{-1}, 37.5 \mu \mathrm{g} \mathrm{mL}^{-1}, 18.8 \mu \mathrm{g} \mathrm{mL}^{-1}\right.$, $9.4 \mu \mathrm{g} \mathrm{mL} L^{-1}, 4.7 \mu \mathrm{g} \mathrm{mL}^{-1}, 2.3 \mu \mathrm{g} \mathrm{mL}^{-1}, 1.2 \mu \mathrm{g} \mathrm{mL}^{-1}, 0.59 \mu \mathrm{g}$ $\mathrm{mL}^{-1}$ ) were incorporated in specified quantity of the corresponding sterilized liquid medium. A specified quantity of the medium containing the compound was poured into micro-titration plates. Suspension of the microorganism was prepared to contain approximately $1.0 \times 10^{5} \mathrm{cfu} \mathrm{mL}^{-1}$ and applied to microtitration plates with serially diluted compounds in DMSO to be tested and incubated at $37^{\circ} \mathrm{C}$ for $24 \mathrm{~h}$ and $48 \mathrm{~h}$ for bacteria and fungi, respectively. Then the MIC values were visually determined on each of the microtitration plates, $50 \mu \mathrm{L}$ of PBS (phosphate buffered saline $0.01 \mathrm{~mol} \mathrm{~L}^{-1}, \mathrm{pH}=7.4$ ) containing $2 \mathrm{mg}$ of MTT mL $\mathrm{mL}^{-1}$ was added to each well. Incubation was continued at room temperature for $4-5 \mathrm{~h}$. The content of each well was removed and $100 \mu \mathrm{L}$ solution of isopropanol (95\%) and 1 mol L-1 $\mathrm{HCl}$ (5\%) was added to extract the dye. After $12 \mathrm{~h}$ of incubation at room temperature, the optical density was measured with a microplate reader at $550 \mathrm{~nm}$. 
Table 1. Crystallographic and refinement data for the complexes

\begin{tabular}{|c|c|c|c|}
\hline Complex & 1 & 2 & 3 \\
\hline Formula & $\mathrm{C}_{24} \mathrm{H}_{34} \mathrm{Br}_{4} \mathrm{CuN}_{4} \mathrm{O}_{2}$ & $\mathrm{C}_{26} \mathrm{H}_{34} \mathrm{Br}_{2} \mathrm{CuN}_{6} \mathrm{O}_{2} \mathrm{~S}_{2}$ & $\mathrm{C}_{24} \mathrm{H}_{34} \mathrm{Br}_{2} \mathrm{CuN}_{6} \mathrm{O}_{8}$ \\
\hline Formula weight & 793.73 & 750.07 & 757.93 \\
\hline$T(\mathrm{~K})$ & $298(2)$ & $298(2)$ & $298(2)$ \\
\hline Crystal system & Monoclinic & Orthorhombic & Triclinic \\
\hline Space group & $P 2_{1} / n$ & $P b c a$ & $P-1$ \\
\hline$a(\AA)$ & $12.5850(13)$ & $13.6410(18)$ & $5.8585(11)$ \\
\hline$b(\AA)$ & $17.8439(10)$ & $9.7930(16)$ & $10.4956(12)$ \\
\hline$c(\AA)$ & $14.2664(12)$ & $23.2285(16)$ & $12.5848(13)$ \\
\hline$\alpha\left({ }^{\circ}\right)$ & 90 & 90 & $86.090(1)$ \\
\hline$\beta\left({ }^{\circ}\right)$ & $109.717(1)$ & 90 & $82.966(1)$ \\
\hline$\gamma\left({ }^{\circ}\right)$ & 90 & 90 & $84.240(1)$ \\
\hline$V\left(\AA^{3}\right)$ & $3015.9(4)$ & $3103.0(7)$ & $762.9(2)$ \\
\hline$Z$ & 4 & 4 & 1 \\
\hline$D_{\text {calc }}\left(\mathrm{g} \mathrm{cm}^{-3}\right)$ & 1.748 & 1.606 & 1.650 \\
\hline$\mu(\mathrm{Mo} \mathrm{Ka})\left(\mathrm{mm}^{-1}\right)$ & 6.051 & 3.448 & 3.389 \\
\hline$F(000)$ & 1564 & 1516 & 383 \\
\hline Measured reflections & 16027 & 15250 & 4017 \\
\hline Unique reflections & 5617 & 2891 & 2806 \\
\hline Observed reflections $(I \geq 2 \sigma(I))$ & 2929 & 2047 & 2076 \\
\hline Parameters & 344 & 180 & 189 \\
\hline Restraints & 42 & 0 & 0 \\
\hline GOOF & 1.005 & 1.102 & 1.129 \\
\hline$R_{1}, w R_{2}\left[I^{3} 2 s(I)\right]^{a}$ & $0.0480,0.1064$ & $0.0654,0.1633$ & $0.0492,0.1544$ \\
\hline$R_{1}, w R_{2}(\text { all data })^{a}$ & $0.1176,0.1342$ & $0.0936,0.1780$ & $0.0693,0.1701$ \\
\hline
\end{tabular}

\footnotetext{
${ }^{\mathrm{a}} R_{1}=\Sigma|| F_{\mathrm{o}}|-| F_{\mathrm{c}}|| / \Sigma\left|F_{\mathrm{o}}\right|, w R_{2}=\left\{\Sigma\left[w\left(F_{\mathrm{o}}{ }^{2}-F_{\mathrm{c}}{ }^{2}\right)^{2}\right] / \Sigma\left[w\left(F_{\mathrm{o}}{ }^{2}\right)^{2}\right\}^{1 / 2}\right.$
}

Table 2. Selected bond distances $(\AA)$ and angles $\left(^{\circ}\right)$ for the complexes

\begin{tabular}{lccc}
\hline $\mathbf{1}$ & & & \\
$\mathrm{Cu} 1-\mathrm{O} 1$ & $1.907(4)$ & $\mathrm{Cu} 1-\mathrm{O} 2$ & $1.908(4)$ \\
$\mathrm{Cu} 1-\mathrm{N} 1$ & $1.985(5)$ & $\mathrm{Cu} 1-\mathrm{N} 3$ & $1.983(5)$ \\
O2-Cu1-O1 & $165.1(2)$ & $\mathrm{O} 2-\mathrm{Cu} 1-\mathrm{N} 3$ & $92.6(2)$ \\
O1-Cu1-N3 & $88.3(2)$ & $\mathrm{O} 2-\mathrm{Cu} 1-\mathrm{N} 1$ & $88.1(2)$ \\
O1-Cu1-N1 & $91.8(2)$ & $\mathrm{N} 3-\mathrm{Cu} 1-\mathrm{N} 1$ & $177.1(2)$ \\
$\mathbf{2}$ & & & \\
Cu1-O1 & $1.954(4)$ & $\mathrm{Cu} 1-\mathrm{N} 1$ & $2.014(5)$ \\
O1-Cu1-O1A & 180 & $\mathrm{O} 1-\mathrm{Cu} 1-\mathrm{N} 1$ & $90.22(19)$ \\
O1-Cu1-N1A & $89.78(19)$ & $\mathrm{N} 1-\mathrm{Cu} 1-\mathrm{N} 1 \mathrm{~A}$ & 180 \\
Symmetry code for A: $1-x,-y,-z$. & & \\
$\mathbf{3}$ & & & $2.009(4)$ \\
Cu1-O1 & $1.913(3)$ & $\mathrm{Cu} 1-\mathrm{N} 1$ & $\mathbf{8 8 . 5 8}(16)$ \\
O1-Cu1-O1A & 180 & $\mathrm{O} 1-\mathrm{Cu} 1-\mathrm{N} 1 \mathrm{~A}$ & 180 \\
O1-Cu1-N1 & $91.42(16)$ & $\mathrm{N} 1-\mathrm{Cu} 1-\mathrm{N} 1 \mathrm{~A}$ & \\
Symmetry code for A: $1-x, 1-y, 1-z$. & & & \\
\hline
\end{tabular}

\section{Results and Discussion}

\section{1. Synthesis and Characterization}

The Schiff base HL was readily prepared by the reaction of equimolar quantities of 3-bromosalicylaldehyde and $\mathrm{N}$-isopropylethane-1,2-diamine in methanol. Complex 1 was prepared by the reaction of HL with copper bromide in methanol. Complex 2 was prepared by the similar method as complex $\mathbf{1}$, followed by the addition of ammonium thiocyanate. Complex $\mathbf{3}$ was prepared by the similar method as complex 1, but with copper bromide replaced with copper nitrate (Scheme 1). Single crystals of the complexes were obtained by slow evaporation of their methanolic solution. From the preparation of complexes $\mathbf{1}$ and $\mathbf{2}$, it can be seen that the bromide anions can be replaced by thiocyanate anions. Elemental analyses of the complexes 
<smiles>CC(C)NCC/N=C/c1cccc(Br)c1O</smiles><smiles>CCOc1c(/C=N/N(CCNC(C)C)CCNC(C)C)ccc(C)c1Br</smiles>

Scheme 1. The synthetic procedure for $\mathrm{HL}$ and the complexes. $\mathrm{MX}=\mathrm{CuBr}_{2}$ for $\mathbf{1}, \mathrm{CuBr}_{2}$ and $\mathrm{NH}_{4} \mathrm{NCS}$ for $\mathbf{2}$, and $\mathrm{Cu}\left(\mathrm{NO}_{3}\right)_{2}$ for 3 .

are in accordance with the molecular structures determined by the single crystal X-ray analysis.

\section{2. Spectroscopic Studies}

The typical and strong absorptions at 1618-1619 $\mathrm{cm}^{-1}$ of the complexes are generated by the vibrations of the $\mathrm{C}=\mathrm{N}$ bonds, indicating the formation of the Schiff bases from the condensation reaction of the 3-bromosalicylaldehyde and $\mathrm{N}$-isopropylethane-1,2-diamine during the coordination. ${ }^{11}$ The intense absorption at $2038 \mathrm{~cm}^{-1}$ for complex $\mathbf{2}$ is attributed to the stretching vibration of the thiocyanate anions. ${ }^{12}$ The spectrum of complex 3

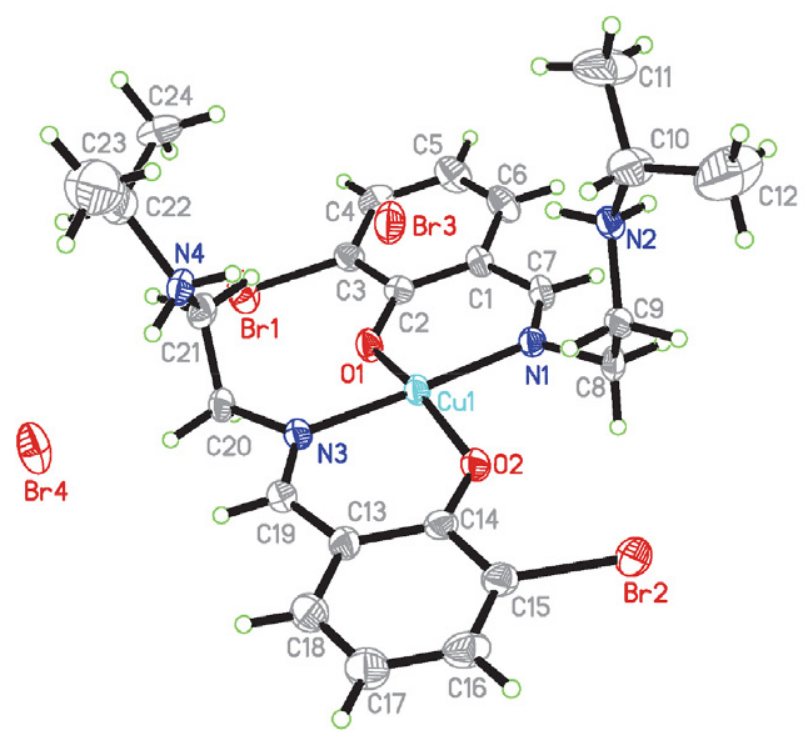

Figure 1. A perspective view of complex 1 with the atom labeling scheme. Thermal ellipsoids are drawn at the $30 \%$ probability level. shows an intense band at $1382 \mathrm{~cm}^{-1}$ characteristic of ionic nitrate. $^{13}$

In the UV-Vis spectra of the complexes, the bands at 370-373 nm are attributed to the azomethine chromophore $\pi \rightarrow \pi^{*}$ transition. ${ }^{14}$ The bands at higher energies (220-222 and 247-267 nm) are associated with the benzene $\pi \rightarrow \pi^{*}$ transition. ${ }^{14}$

\section{3. Structure Description of the Complexes}

Molecular structures of complexes 1-3 are shown in Figures 1-3, respectively. All the complexes contain

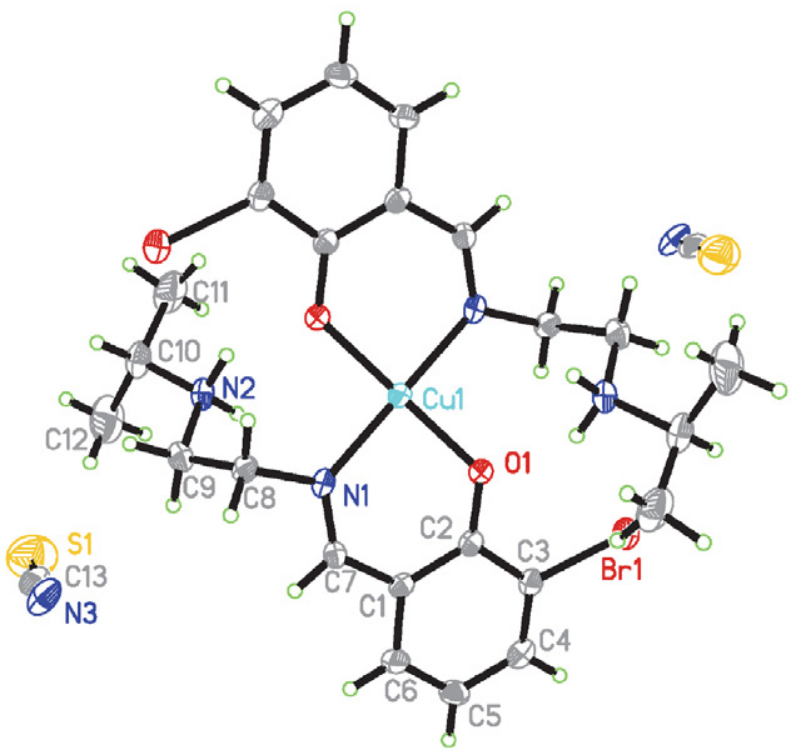

Figure 2. A perspective view of complex $\mathbf{2}$ with the atom labeling scheme. Thermal ellipsoids are drawn at the $30 \%$ probability level. The unlabeled atoms are related to the symmetry operation $1-x,-y,-z$. 
$\left[\mathrm{Cu}(\mathrm{LH})_{2}\right]^{2+}$ cations, and two anions, viz. $\mathrm{Br}^{-}$for $\mathbf{1}, \mathrm{SCN}^{-}$for 2 , and $\mathrm{NO}_{3}{ }^{-}$for 3 . The $\mathrm{Cu}$ atoms in the cations are coordinated in square planar geometry, with the phenolate $\mathrm{O}$ and imino $\mathrm{N}$ atoms of the Schiff base ligand LH. The Schiff base ligand, acts as a bidentate ligand, chelate the $\mathrm{Cu}$ atoms by generating one six-membered ring with bite angles of $88.1(2)^{\circ}$ and $92.6(2)^{\circ}$ for $1,89.78(19)^{\circ}$ and $90.22(19)^{\circ}$ for 2 , and $88.58(16)^{\circ}$ and $91.42(16)^{\circ}$ for 3 , respectively. The trans angles in the complexes are $1651(2)^{\circ}$ and $177.11(2)^{\circ}$ for 1 , and $180^{\circ}$ for 2 and 3. Thus, the bond lengths and angles in the square planar coordination are similar to each other, and comparable to those in the reported Schiff base copper complexes. ${ }^{15}$

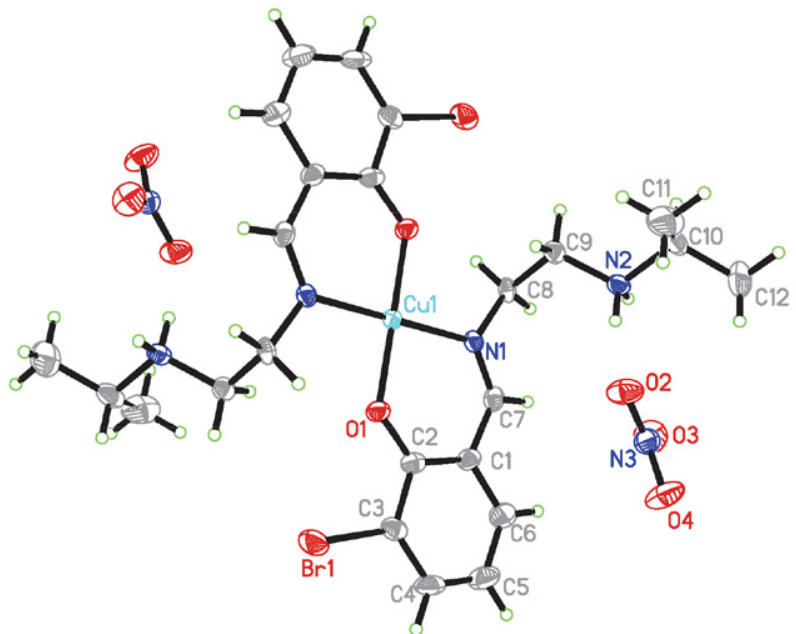

Figure 3. A perspective view of complex 3 with the atom labeling scheme. Thermal ellipsoids are drawn at the $30 \%$ probability level. The unlabeled atoms are related to the symmetry operation $1-x, 1$ $-y, 1-z$.

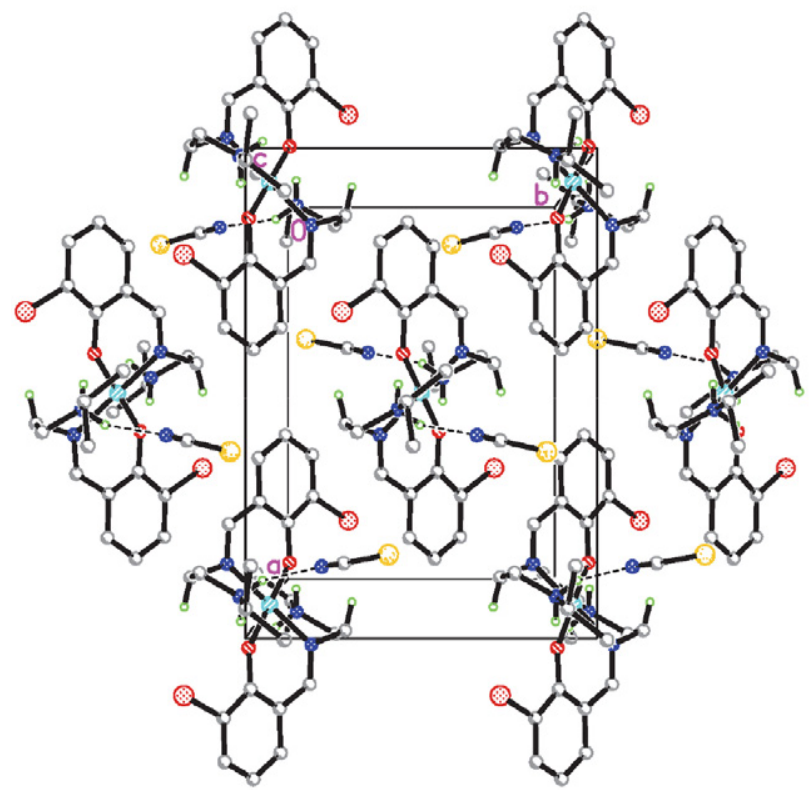

Figure 5. Molecular packing structure of complex 2, viewed along the $c$ axis. Hydrogen bonds are shown as dashed lines.

In the crystal structure of complex $\mathbf{1}$, the $\left[\mathrm{Cu}(\mathrm{LH})_{2}\right]^{2+}$ cations and the $\mathrm{Br}^{-}$anions are linked through hydrogen bonds of $\mathrm{N}-\mathrm{H} \cdots \mathrm{Br}$ and $\mathrm{C}-\mathrm{H} \cdots \mathrm{Br}$, to form two-dimensional sheets parallel to the $b c$ plane (Figure 4 ). In the crystal structure of complex 2, the $\left[\mathrm{Cu}(\mathrm{LH})_{2}\right]^{2+}$ cations and the $\mathrm{SCN}^{-}$ anions are linked through hydrogen bonds of $\mathrm{N}-\mathrm{H} \cdots \mathrm{N}$ (Figure 5). In the crystal structure of complex 3 , the $\left[\mathrm{Cu}(\mathrm{LH})_{2}\right]^{2+}$ cations and the $\mathrm{NO}_{3}{ }^{-}$anions are linked through hydrogen bonds of $\mathrm{C}-\mathrm{H} \cdots \mathrm{Br}$ and $\mathrm{N}-\mathrm{H} \cdots \mathrm{O}$, to form one-dimensional chains running along the $c$ axis (Figure 6).

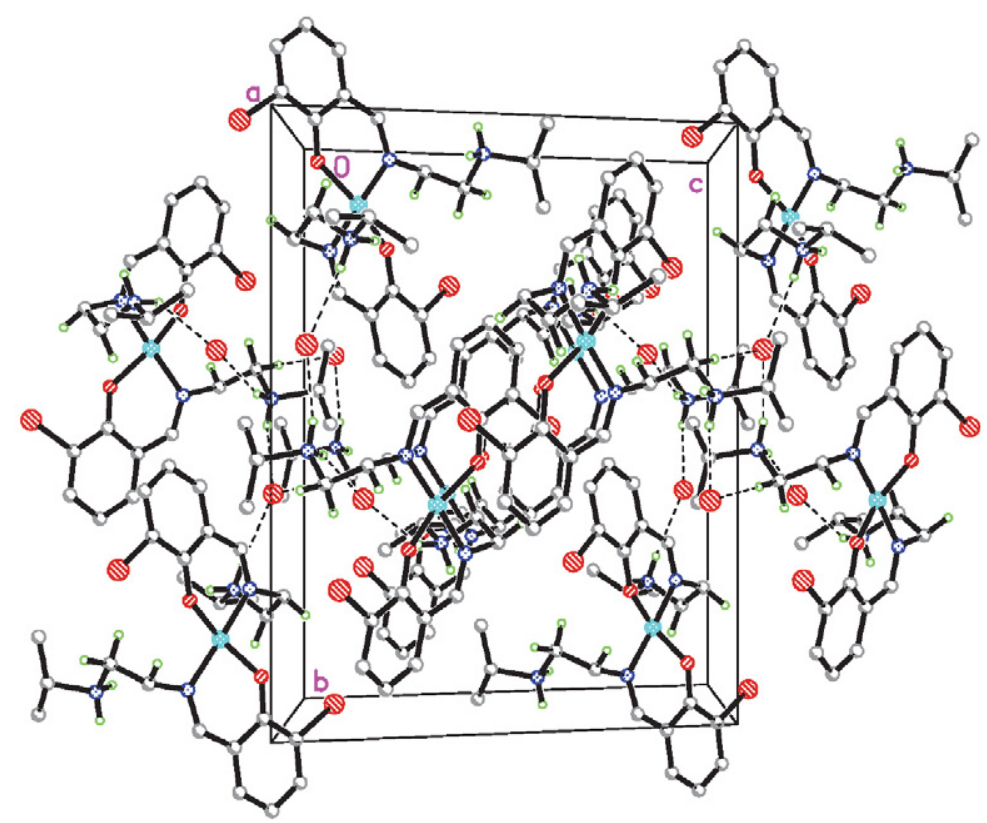

Figure 4. Molecular packing structure of complex 1, viewed along the $a$ axis. Hydrogen bonds are shown as dashed lines. 


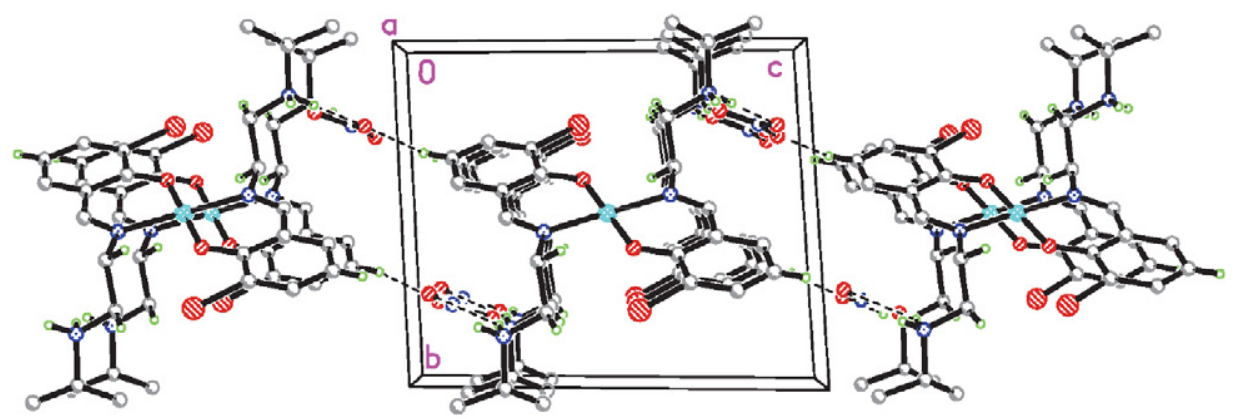

Figure 6. Molecular packing structure of complex 3, viewed along the $a$ axis. Hydrogen bonds are shown as dashed lines.

Table 3. Distances $(\AA)$ and angles $\left(^{\circ}\right)$ involving hydrogen bonding of the complexes

\begin{tabular}{lcccc}
\hline $\boldsymbol{D}-\mathbf{H} \cdots \boldsymbol{A}$ & $\mathbf{d}(\boldsymbol{D}-\mathbf{H})$ & $\mathbf{d}(\mathbf{H} \cdot \boldsymbol{A})$ & $\mathbf{d}(\boldsymbol{D} \cdots \boldsymbol{A})$ & Angle $(\boldsymbol{D}-\mathbf{H} \cdots \boldsymbol{A})$ \\
\hline $\mathbf{1}$ & & & & \\
$\mathrm{N} 4-\mathrm{H} 4 \mathrm{~B} \cdots \mathrm{Br} 4$ & 0.89 & 2.45 & $3.313(6)$ & $164(5)$ \\
$\mathrm{N} 4-\mathrm{H} 4 \mathrm{~A} \cdots \mathrm{Br} 3$ & 0.89 & 2.41 & $3.238(5)$ & $155(5)$ \\
$\mathrm{N} 2-\mathrm{H} 2 \mathrm{~B} \cdots \mathrm{Br} 4^{\mathrm{i}}$ & 0.89 & 2.42 & $3.309(5)$ & $175(5)$ \\
$\mathrm{N} 2-\mathrm{H} 2 \mathrm{~A} \cdots \mathrm{Br} 3$ & 0.89 & 2.46 & $3.216(5)$ & $143(5)$ \\
$\mathrm{C} 21-\mathrm{H} 21 \mathrm{~B} \cdots \mathrm{Br} 4^{\mathrm{ii}}$ & 0.97 & 2.89 & $3.848(8)$ & $171(5)$ \\
$\mathbf{2}$ & & & & \\
$\mathrm{N} 2-\mathrm{H} 2 \mathrm{~B} \cdots \mathrm{N} 3^{\mathrm{iii}}$ & 0.90 & 2.15 & $3.000(8)$ & $156(7)$ \\
$\mathbf{3}$ & & & & \\
$\mathrm{N} 2-\mathrm{H} 2 \mathrm{~A} \cdots \mathrm{O} 2^{\text {iv }}$ & 0.89 & 2.59 & $3.130(6)$ & $120(6)$ \\
$\mathrm{N} 2-\mathrm{H} 2 \mathrm{~A} \cdots 4^{\text {iv }}$ & 0.89 & 2.01 & $2.898(7)$ & $174(6)$ \\
$\mathrm{N} 2-\mathrm{H} 2 \mathrm{~B} \cdots \mathrm{O} 3$ & 0.89 & 2.52 & $3.169(6)$ & $131(6)$ \\
$\mathrm{C} 8-\mathrm{H} 8 \mathrm{~A} \cdots 1^{\mathrm{v}}$ & 0.97 & 2.30 & $2.752(6)$ & $107(6)$ \\
\hline
\end{tabular}

Symmetry codes: i: $1 \frac{1 / 2}{2}-x, 1 / 2+y, 1 / 2-z$; ii: $2-x, 1-y,-z$; iii: $x,-1+y, z$; iv: $-1+x, y, z$; v: $1-x, 1-y, 1-z$

\section{4. Antimicrobial Activity}

The three complexes were screened for antibacterial activities against two Gram (+) bacterial strains (Bacillus subtilis and Staphylococcus aureus) and two Gram (-) bacterial strains (Escherichia coli and Pseudomonas fluorescence) by MTT method. The MIC (minimum inhibitory concentration, $\mu \mathrm{g} \mathrm{mL}^{-1}$ ) values of the compounds against four bacteria are listed in Table 4. Penicillin G was used as the standard drug. As expected, the three complexes have the same activities against all the bacteria within the standard uncertainty. Since the difference of the three complexes is the anions, it is easy to conclude that the anions like bromide, thiocyanate and nitrate do not have obvious influence on the antibacterial activity. All the complexes show strong activity against $B$. subtilis and $S$. aureus, and medium activity against $E$. coli, while weak activity against P. fluorescence. For the bacteria B. subtilis, S. aureus and E. coli, the complexes have stronger activities than copper bromide and Penicillin G. However, for the bacteria P. fluorescence, the complexes have weaker activities than copper bromide, while stronger activities than Penicillin G. However, all the complexes have no activity on the fungal strains Candida albicans and Aspergillus niger. The present complexes have higher activities against B. subtilis, $S$. aureus and $E$. coli, when compared with the vanadium complex with hydrazone ligands, ${ }^{16}$ and the copper complexes with Schiff bases. ${ }^{17}$

Table 4. Antibacterial activities of the complexes with minimum inhibitory concentrations ( $\mu \mathrm{g}$ $\left.\mathrm{mL}^{-1}\right)$

\begin{tabular}{lcccc}
\hline Tested material & B. subtilis & S. aureus & E. coli & P. fluorescence \\
\hline $\mathbf{1}$ & 1.2 & 2.3 & 9.4 & 37.5 \\
$\mathbf{2}$ & 1.2 & 2.3 & 9.4 & 37.5 \\
$\mathbf{3}$ & 1.2 & 2.3 & 9.4 & 37.5 \\
Copper bromide & 4.7 & 9.4 & 37.5 & 9.4 \\
Penicillin G & 2.3 & 4.7 & $>150$ & $>150$ \\
\hline
\end{tabular}




\section{Conclusion}

Three new structurally similar mononuclear Schiff base copper(II) complexes with the cation $\left[\mathrm{Cu}(\mathrm{LH})_{2}\right]^{2+}$ and different anions were synthesized from the Schiff base 2-bromo-6-((2-(isopropylamino)ethylimino)methyl)phenol. The complexes have been characterized by physico-chemical method, and their structures have been confirmed by single crystal X-ray structure determination. The $\mathrm{Cu}$ atoms in the complexes are in square planar coordination. The complexes have strong activities against the bacteria B. subtilis, S. aureus and E. coli.

\section{Supplementary Data}

CCDC 2095686 (1), 2095687 (2) and 2095688 (3) contain the supplementary crystallographic data for the compounds. These data can be obtained free of charge via http://www.ccdc.cam.ac.uk/conts/retrieving.html, or from the Cambridge Crystallographic Data Centre, 12 Union Road, Cambridge CB2 1EZ, UK; fax: (+44) 1223-336-033; or e-mail: deposit@ccdc.cam.ac.uk.

\section{Acknowledgments}

This work was financially supported by K. C. Wong Magna Fund in Ningbo University, Ningbo Public Fund (Project No. 202002N3056), the State Key Laboratory Development Fund of Structural Chemistry (Project No. 20190028), and the Ningbo Public Welfare Funds (Project Nos. 202002N3056 and 2021S142).

\section{References}

1. M. H. Esfahani, H. Iranmanesh, J. E. Beves, M. Kaur, J. P. Jasinski, M. Behzad. J. Coord. Chem. 2019, 72, 2326-2336.

DOI:10.1080/00958972.2019.1643846

2. (a) S. Mandal, M. Layek, R. Saha, C. Rizzoli, D. Bandyopadhyay, Transition Met. Chem. 2020, 46, 9-16;

DOI:10.1007/s11243-020-00416-6

(b) M. H. Esfahani, M. Behzad, J. Coord. Chem. 2020, 73, 154-163; DOI:10.1080/00958972.2020.1725492

(c) N. Caliskan, A. Usta, F. S. Beris, N. Baltas, E. Celik, Lett. Org. Chem. 2020, 17, 631-638;

DOI: $10.2174 / 1570178617666200108111211$

(d) S. Mandal, T. Sen, U. Mandal, D. Bhunia, C. Rizzoli, D. Bandyopadhyay, J. Coord. Chem. 2019, 72, 3614-3624;

DOI:10.1080/00958972.2019.1704275

(e) A. Frei, A. P. King, G. J. Lowe, A. K. Cain, F. L. Short, H. Dinh, A. G. Elliott, J. Zuegg, J. J. Wilson, M. A. T. Blaskovich, Chem. Eur. J. 2020, 27, 2021-2029;

DOI: $10.1002 /$ chem. 202003545

(f) P.-L. Lam, K. K.-H. Lee, S. H.-L. Kok, R. Gambari, K.-H. Lam, C.-L. Ho, X. Ma, Y.-H. Lo, W.-Y. Wong, D.-C. Dong, Z.X. Bian, C.-H. Chui, RSC Advances 2016, 6, 104575-104581;

\section{DOI:10.1039/C6RA20186E}

(g) K. Venkateswarlu, N. Ganji, S. Daravath, K. Kanneboina, K. Rangan, Shivaraj, Polyhedon 2019, 171, 86-97;

DOI:10.1016/j.poly.2019.06.048

(h) N. R. Palepu, S. L. Nongbri, J. R. Premkumar, A. K. Verma, K. Bhattacharjee, S. R. Joshi, S. Forbes, Y. Mozharivskyj, R. Thounaojam, K. Aguan, M. R. Kollipara, J. Biol. Inorg. Chem. 2015, 20, 619-638. DOI:10.1007/s00775-015-1249-3

3. (a) G. Paraskevopoulos, S. Monteiro, R. Vosatka, M. Kratky, L. Navratilova, F. Trejtnar, J. Stolarikova, J. Vinsova, Bioorg. Med. Chem. 2017, 25, 1524-1532;

DOI:10.1016/j.bmc.2017.01.016

(b) M. Zhang, D.-M. Xian, H.-H. Li, J.-C. Zhang, Z.-L. You, Aust. J. Chem. 2012, 65, 343-350; DOI:10.1071/CH11424

(c) H.-F. Guo, Y. Pan, D.-Y. Ma, P. Yan, Chinese J. Inorg. Chem. 2013, 29, 1447-1453.

4. N. P. Rai, V. K. Narayanaswamy, T. Govender, B. K. Manuprasad, S. Shashikanth, P. N. Arunachalam, Eur. J. Med. Chem. 2010, 45, 2677-2682. DOI:10.1016/j.ejmech.2010.02.021

5. A. Bhattacharjee, S. Das, B. Das, P. Roy, Inorg. Chim. Acta 2021, 514, 119961; DOI:10.1016/j.ica.2020.119961

(b) S. Mandal, M. Layek, R. Saha, C. Rizzoli, D. Bandyopadhyay, Transition Met. Chem. 2020, 46, 9-16;

DOI:10.1007/s11243-020-00416-6

(c) M. H. Esfahani, M. Behzad, J. Coord. Chem. 2020, 73, 154-163; DOI:10.1080/00958972.2020.1725492

(d) N. Rajendran, A. Periyasamy, N. Kamatchi, V. Solomon, J. Coord. Chem. 2019, 72, 1937-1956.

DOI:10.1080/00958972.2019.1634806

6. C.-L. Zhang, X.-Y. Qiu, S.-J. Liu, Acta Chim. Slov. 2019, 66, 719-725; DOI:10.17344/acsi.2019.5241

(b) L.-Y. He, X.-Y. Qiu, J.-Y. Cheng, S.-J. Liu, S.-M. Wu, Polyhedron 2018, 156, 105-110; DOI:10.1016/j.poly.2018.09.017 (c) S. M. Wu, X. Y. Qiu, J. C. Wang, S. J. Liu, L. Y. He, Russ. J. Coord. Chem. 2019, 45, 384-390.

7. Bruker, SMART (Version 5.625) and SAINT (Version 6.01). Bruker AXS Inc., Madison, Wisconsin, USA, 2007.

8. G. M. Sheldrick, SADABS. Program for Empirical Absorption Correction of Area Detector, University of Göttingen, Germany, 1996.

9. G. M. Sheldrick, SHELXTL V5.1 Software Reference Manual, Bruker AXS, Inc., Madison, Wisconsin, USA, 1997.

10. J. Meletiadis, J. F. G. M. Meis, J. W. Mouton, J. P. Donnelly, P. E. Verweij, J. Clin. Microbiol. 2000, 38, 2949-2954. DOI:10.1128/JCM.38.8.2949-2954.2000

11. (a) S. Manna, E. Zangrando, H. Puschmann, S. C. Manna, Polyhedron 2019, 162, 285-292; DOI:10.1016/j.poly.2019.01.057 (b) P. Chakraborty, S. Majumder, A. Jana, S. Mohanta, Inorg. Chim. Acta 2014, 410, 65-75. DOI:10.1016/j.ica.2013.10.013

12. (a) M. Sarwar, A. M. Madalan, F. Lloret, M. Julve, M. Andruh, Polyhedron 2011, 30, 2414-2420;

DOI:10.1016/j.poly.2011.06.011

(b) J. Nishijo, T. Yoshida, M. Enomoto, Polyhedron 2015, 87, 233-236. DOI:10.1016/j.poly.2014.11.015

13. (a) M. F. Iskander, T. E. Khalil, R. Werner, W. Haase, I. Svoboda, H. Fuess, Polyhedron 2000, 19, 949-958; 
DOI:10.1016/S0277-5387(00)00340-5

(b) S. Chandra, A. K. Sharma, J. Coord. Chem. 2009, 62, 3688-3700. DOI:10.1080/00958970903121305

14. L. Pogany, J. Moncol, M. Gal, I. Salitros, R. Boca, Inorg. Chim. Acta 2017, 462, 23-29. DOI:10.1016/j.ica.2017.03.001

15. (a) D. Aggoun, M. Fernandez-Garcia, D. Lopez, B. Bouzerafa, Y. Ouennoughi, F. Setifi, A. Ourari, Polyhedron 2020, 187, 114640; DOI:10.1016/j.poly.2020.114640

(b) H. Kargar, R. Behjatmanesh-Ardakani, V. Torabi, A. Sarvian, Z. Kazemi, Z. Chavoshpour-Natanzi, V. Mirkhani, A. Sahraei, M. N. Tahir, M. Ashfaq, Inorg. Chim. Acta 2021, 514, 120004; DOI:10.1016/j.ica.2020.120004 (c) T. L. Yusuf, S. D. Oladipo, S. Zamisa, H. M. Kumalo, I. A. Lawal, M. M. Lawal, N. Mabuba, ACS Omega 2021, 6, 13704-13718. DOI:10.1021/acsomega.1c00906

16. (a) H.-Y. Qian, Acta Chim. Slov. 2019, 66, 995-1001; DOI:10.4149/neo_2019_190112N36

(b) Z.-Q. Sun, S.-F. Yu, X.-L. Xu, X.-Y. Qiu, S.-J. Liu, Acta Chim. Slov. 2020, 67, 1281-1289.

DOI:10.17344/acsi.2020.6236

17. S.-F. Yu, X.-Y. Qiu, S.-J. Liu, Acta Chim. Slov. 2020, 67, 13011308. DOI:10.17344/acsi.2020.6321

\section{Povzetek}

Sintetizirali smo tri nove bakrove(II) komplekse, $\left[\mathrm{Cu}(\mathrm{LH})_{2}\right] \mathrm{Br}_{2}(\mathbf{1}),\left[\mathrm{Cu}(\mathrm{LH})_{2}\right] \mathrm{NCS}_{2}(\mathbf{2})$ in $\left[\mathrm{Cu}(\mathrm{LH})_{2}\right]\left(\mathrm{NO}_{3}\right)_{2}(\mathbf{3})$, kjer je LH ion-dvojček 2-bromo-6-((2-(izopropilamino)etilimino)metil)fenola (HL), in jih okarakterizirali z elementarno analizo, IR in UV-vis spektroskopijo. Strukture kompleksov so bile dodatno potrjene z določitvijo monokristalne rentgenske strukture. Vse spojine so enojedrni bakrovi(II) kompleksi. Cu atomi v kompleksih so koordinirani $\mathrm{z}$ dvema imino $\mathrm{N}$ in dvema fenolato $\mathrm{O}$ atomoma iz dveh LH ligandov, kar tvori kvadratno planarno koordinacijo. Pri spojinah smo ugotavljali njihovo protimikrobno delovanje. 